\title{
METHODS FOR OVERCOMING SEED DORMANCY AND THE INITIAL GROWTH OF Ziziphus joazeiro Mart. IN DIFFERENT SOILS ${ }^{1}$
}

\author{
JOSENARA DAIANE DE SOUZA COSTA ${ }^{2}$, JOSÉ ALIÇANDRO BEZERRA DA SILVA ${ }^{3}$, DANIELA SIQUEIRA \\ $\mathrm{COELHO}^{4}$, ÍTALO EMANUEL DOS ANJOS SANTOS ${ }^{3}$, TALES XAVIER SEABRA ${ }^{3}$
}

\begin{abstract}
Considering the potential and importance of biodiversity of the Caatinga biome, studies on endemic species are relevant to conservation of its natural resources. The objectives of this work was to evaluate seed viability and physical methods for overcoming seed dormancy in juazeiro (Ziziphus joazeiro Mart.) and assess the influence of different types of soil on the initial growth of juazeiro plants. The experiments were conducted in three stages. In the first stage, the viability of seeds from different lots was evaluated using the tetrazolium test. The second stage was conducted in a plant nursery, evaluating the application of physical processes (scarification with sandpaper and hammer) in overcoming seed dormancy, and the initial growth of the plants. In the third step, the chlorophyll $a$ and $b$ contents, gas exchange and dry matter accumulation were evaluated in young juazeiro plants in three types of soil (Oxisol, Entisol and Vertisol). The results indicate that the viability of juazeiro seeds is greatly influenced by differences between the progenitor plants and by storage conditions, which enable a longevity of two years when stored at $22^{\circ} \mathrm{C}$ and $16 \%$ of relative humidity. The scarification methods with sandpaper and hammer are not efficient to reduce the time and uniform seed germination. The juazeiro plants have high growth potential in different edaphic environments, adapting well to soils of different textures and chemical compositions.
\end{abstract}

Keywords: Juazeiro. Emergence. Gas exchange. Chlorophyll index. Soil.

\section{SUPERAÇÃO DE DORMÊNCIA EM SEMENTES E CRESCIMENTO INICIAL DE Ziziphus joazeiro Mart. EM DIFERENTES SOLOS}

\begin{abstract}
RESUMO - Considerando as potencialidades e importância da biodiversidade do bioma Caatinga, estudos sobre espécies endêmicas são relevantes para conservação de seus recursos naturais. Objetivou-se com este trabalho avaliar a viabilidade e a superação de dormência de sementes de juazeiro (Ziziphus joazeiro Mart.) e seu o crescimento inicial em diferentes tipos de solo. Os experimentos foram conduzidos em três etapas. Na primeira, avaliou-se a viabilidade de diferentes lotes de sementes, utilizando o teste de tetrazólio. A segunda etapa foi conduzida em viveiro, avaliando-se as aplicações de processos físicos, escarificação com lixa e com martelo, para superação da dormência das sementes e determinação do crescimento inicial das plantas. Na última etapa foram avaliados os índices de clorofila $a$ e $b$, as trocas gasosas e o acúmulo de matéria seca em plantas jovens de juazeiro em três tipos de solo (Latossolo, Neossolo e Vertissolo). A partir dos resultados obtidos pode-se afirmar que a viabilidade das sementes de juazeiro é bastante influenciada pelas diferenças existentes entre plantas matrizes e pelas condições de armazenamento, apresentando longevidade de dois anos, quando armazenadas a $22{ }^{\circ} \mathrm{C}$ e $16 \%$ de umidade relativa. Os métodos de escarificação com lixa e martelo não são eficientes para reduzir o tempo e uniformizar a geminação das sementes. As plantas de juazeiro apresentam elevado potencial para se desenvolver em diferentes ambientes edáficos, adaptando-se bem a solos com diferentes texturas e composições químicas.
\end{abstract}

Palavras-chave: Juazeiro. Emergência. Trocas gasosas. Índice de clorofila. Solo.

\footnotetext{
*Corresponding author

${ }^{1}$ Received for publication in $08 / 03 / 2015$; accepted in $02 / 10 / 2016$.

Paper extracted from the bachelor final project of the first author.

${ }^{2}$ Department of Agricultural Engineering, Universidade Federal de Campina Grande, Campina Grande, PB, Brazil; josenara.costa@gmail.com.

${ }^{3}$ College Academic of Environmental an Agricultural Engineering, Universidade Federal do Vale do São Francisco, Juazeiro, BA, Brazil; jose.alicandro@univasf.edu.br, italoemannuelanjos@gmail.com, tales.xs@hotmail.com.

${ }^{4}$ Department of Soil, Universidade Federal Rural de Pernambuco, Recife, PE, Brazil; daniela.coelho@hotmail.com.
} 


\section{INTRODUCTION}

The Caatinga is an exclusively Brazilian biome that covers about $10 \%$ of the country area, with most of its area in Northeastern Brazil (BRAZIL, 2015). The Caatinga vegetation is important for biodiversity conservation, mainly due to its high level of endemism (ALVES et al., 2013), however, this biome is one of the least studied, known and protected in the country (SANTANA et al., 2009).

The juazeiro (Ziziphus joazeiro Mart.) is among the plant species classified as endemic to the Caatinga biome, it is an evergreen, medium size tree, which remains green during dry periods because its broad and deep root system (NADIA; MACHADO; LOPES, 2007; OLIVEIRA et al., 2012). However, some factors such as the difficulty of seed germination (ALVES et al., 2006) and slow growth (LACERDA et al., 2011) endanger the survival of this species, especially considering the gradual destruction of native vegetation due to the uncontrolled expansion of human activities.

Therefore, studies that effectively contribute to accelerate germination, growth and development of juazeiro trees are important to its preservation, especially to help recover degraded areas and afforestation (ARAÚJO-NETO et al., 2002; DANTAS; MATIAS; RIBEIRO, 2015).

The seed germination capacity is an important aspect in the preservation of plant species, which can vary significantly between progenitors. This aspect can be evaluated using the tetrazolium test, which is a simple method that helps in the selection of the most viable seeds, and is successfully used in various forest species, such as Amburana cearensis (GUEDES et al., 2010), Erythrina velutina (BENTO et al., 2010) and Tabebuia roseoalba (ABBADE; TAKAKI, 2014).

Seed dormancy is another factor that can affect the germination of native species. In juazeiro, this phenomenon has been associated with the presence of a hard endocarp, whose resistance can be overcome by scarification processes (ALVES et al., 2006), resulting in rupture or weakening of the tegument, facilitating the absorption of water by the seed. However, the scarification effectiveness may vary with the species and the method application form (AZEREDO et al., 2010).

The plant growth and development, as well as the germination, are directly influenced by the edaphoclimatic conditions in which they are grown. The soil contributes to provide water and nutrients (MEURER, 2007), plant support, root development and aeration (MOTTA et al., 2006) and medium for important biological activities such as atmospheric nitrogen and carbon fixation and nutrient cycling (DE-POLLI; GUERRA, 1999).

However, soil characteristics vary significantly between environments, and even within a bioclimatic domain such as the Caatinga (OLIVEIRA et al., 2009; ARCOVERDE et al., 2015), differently affecting the growth of plant species.

Therefore, the objectives of this work was to evaluate seed viability and physical methods for overcoming seed dormancy in juazeiro (Ziziphus joazeiro Mart.) and assess the influence of different types of soil on the initial growth of juazeiro plants.

\section{MATERIAL AND METHODS}

The experiments were conducted at the Cytology and Plant Physiology Laboratory (LACIF) and the experimental area of the São Francisco Valley Federal University (UNIVASF), Juazeiro, BA, Brazil $\left(09^{\circ} 25^{\prime} \mathrm{S}, 40^{\circ} 30^{\prime} \mathrm{W}\right.$ and altitude of 371 $\mathrm{m})$. The average annual temperature and rainfall of the experimental area were $24.2^{\circ} \mathrm{C}$ and $430 \mathrm{~mm}$, respectively (CPRM, 2005). The experiments were conducted in three stages:

a) viability test of juazeiro seeds - juazeiro fruits were collected from native trees at the Lower Basin region of the São Francisco Valley and distributed in three lots: Lot 1 - fruits that were collected from four trees in the Petrolina Municipal Park, Pernambuco State $\left(9^{\circ} 23^{\prime} 18^{\prime \prime S}, 40^{\circ} 29^{\prime} 54^{\prime \prime} \mathrm{W}\right.$, $384 \mathrm{~m}$ ) and stored for one year; Lots 2 and 3 - fruits that were collected from three trees in the municipality of Casa Nova, Bahia State $\left(9^{\circ} 09^{\prime} 08^{\prime \prime S}\right.$, $41^{\circ} 01^{\prime} 48^{\prime \prime} \mathrm{W}, 407 \mathrm{~m}$ ) and stored for two and three years, respectively.

The fruits were washed in tap water on a 4 $\mathrm{mm}$ sieve. The mucilage (mesocarp) was completely removed from the seeds, which were then dried at room temperature. The seeds were stored in plastic bags and placed in a desiccant device at $22^{\circ} \mathrm{C}$ and $16 \%$ of relative humidity.

The seed viability tests were performed with seeds from the three lots, previously immersed in distilled water for 12 hours and then, longitudinal cuts were performed in the seeds. Subsequently, five seed halves were immersed in a $3 \mathrm{~mL}$ solution with $0.5 \% \mathrm{~m} / \mathrm{v}$ of the compound 2,3,5-tri-phenyl tetrazolium for $1 \mathrm{~h} 20$ at $40^{\circ} \mathrm{C}$, following the method of França-Neto (1994) adapted for species after preliminary tests.

The seeds were then evaluated individually, observing the internal color. The seed viability was calculated from each lot, considering viable those with strong and uniform carmine red color tissue in more than $50 \%$ of the surface, and non-viable or dead those with percentage below $50 \%$.

A completely randomized experimental design was used with five repetitions, each consisting of 15 seeds. The evaluated variables were: emergence, emergence speed index (ESI), average emergence time (Tm) and emergence relative frequency (Fr). The ESI was calculated following the formula (MAGUIRE, 1962): 


$$
\mathrm{IVE}=\frac{\sum \mathrm{N}_{\mathrm{i}}}{\mathrm{D}_{\mathrm{i}}}
$$

where $N_{i}$ is the daily number of germinated seeds and $D_{i}$ is the number of days after sowing.

The average time and the relative frequency were evaluated following formulas (LABOURIAU; VALADARES, 1976):

$$
\operatorname{Tm}=\frac{\sum\left(\mathrm{N}_{\mathrm{i}} \times \mathrm{D}_{\mathrm{i}}\right)}{\sum \mathrm{N}_{\mathrm{i}}}
$$

and

$$
\mathrm{Fr}=\frac{\mathrm{N}_{\mathrm{i}}}{\sum \mathrm{N}_{\mathrm{i}}}
$$

The experiment was conducted over 73 days, when the emergence stabilized. Data were subjected to analysis of variance and the means compared by the Dunnett test at 5\% probability.

b) initial growth of juazeiro plants in different types of soil - this stage was conducted in a plant nursery, evaluating the plant morphology and gas exchange. Samples of the three soil classes were collected in zigzag from the soil layer $0-20 \mathrm{~cm}$ : Vertisol ( $9^{\circ} 23^{\prime} 36^{\prime \prime} \mathrm{S}, 40^{\circ} 24^{\prime} 22^{\prime \prime} \mathrm{W}$ and $380 \mathrm{~m}$ ), Oxisol $\left(10^{\circ} 28^{\prime} 46^{\prime \prime} \mathrm{S}, 40^{\circ} 12^{\prime} 10^{\prime \prime} \mathrm{W}\right.$ and $\left.546 \mathrm{~m}\right)$ and Entisol $(9$ ${ }^{\circ} 19^{\prime} 8^{\prime \prime} \mathrm{S}, 40^{\circ} 33^{\prime} 01^{\prime \prime} \mathrm{W}$ and $\left.388 \mathrm{~m}\right)$. Soil analyzes were performed at the Soil Laboratory of the Brazilian Company of Agricultural Research (EMBRAPA Semiarid), and the chemical

\begin{tabular}{|c|c|c|c|c|c|c|c|c|c|c|c|c|c|c|c|c|c|}
\hline & C.E & pH & M.O. & $\mathbf{P}$ & $\mathbf{K}$ & $\mathbf{N a}$ & $\mathrm{Ca}$ & Mg & Al & $\mathbf{H}+\mathbf{A l}$ & SB & CTC & V & $\mathrm{Cu}$ & $\mathrm{Fe}$ & Mn & $\mathbf{Z n}$ \\
\hline & $\mathrm{dS} \mathrm{m}{ }^{-1}$ & & $\mathrm{gk} \mathrm{g}_{1}^{-}$ & $\mathrm{mg} \mathrm{dm}_{3}^{-}$ & & & m & & & & & & $\%$ & & $-\mathrm{mg}$ & $m^{-3}-$ & \\
\hline Oxisol & 0.53 & 4.9 & 7.65 & 4.6 & 0.14 & 0.02 & 1.1 & 0.7 & 0.5 & 3.96 & 1.96 & 5.92 & 33 & 0.4 & 38.1 & 16.4 & 0.6 \\
\hline Entisol & 1.03 & 5.4 & 9.83 & 14.7 & 0.11 & 0.08 & 2.5 & 0.3 & 0.05 & 3.13 & 2.99 & 6.12 & 49 & 0.6 & 101 & 13.7 & 1.2 \\
\hline Vertisol & 0.31 & 5.3 & 10.8 & 44.3 & 0.66 & 0.07 & 6.3 & 1.2 & 0.05 & 4.48 & 8.23 & 12.7 & 65 & 3 & 4 & 74.7 & 2.6 \\
\hline
\end{tabular}
characterization presented in Table 1.

Table 1. Chemical characterization of the Oxisol, Entisol and Vertisol used in the experiment

$\mathrm{EC}=$ electrical conductivity of the saturation extract; $\mathrm{OM}=$ organic matter; $\mathrm{P}=$ available phosphorus; $\mathrm{H}+\mathrm{Al}=$ potential acidity; $\mathrm{SB}=$ sum of bases; $\mathrm{CEC}$ = cation exchange capacity; $\mathrm{V}=$ base saturation. Micronutrients and available phosphorus were extracted by Mehlich-1.

Uniform size seedlings from seeds of the lot 2 were transplanted into 12-liter pots, containing soil without fertilization. A completely randomized experimental design was used, with seven replicates. The pots were randomly arranged in the plant nursery, under a $50 \%$ shading spaced at $1.0 \mathrm{~m} \times 1.0$ m. Irrigation was performed daily in order to increase soil moisture to field capacity.

The main branch length and stem diameter of seedlings were measured monthly for five months, using a ruler and caliper, respectively.

Gas exchange was measured (hourly) from $08 \mathrm{~h} 00$ to $15 \mathrm{~h} 00$, using a portable Infrared Gas Analyzer (Li 6400 Licor), by the end of the experiment, 120 days after seedling transplanting. The variables analyzed were: photosynthetically active radiation (PAR), net assimilation rate of $\mathrm{CO}_{2}$ (A), transpiration rate (E), internal $\mathrm{CO}_{2}$ concentration $(\mathrm{Ci})$, stomatal conductance $\left(\mathrm{g}_{\mathrm{s}}\right)$ and leaf surface temperature (Tl). The measurements were performed in the $8^{\text {th }}$ leaf of the $2^{\text {nd }}$ branch from the apex.

The chlorophyll $a$ and $b$ content were evaluated using a chlorophyll measurer (ClorofiLOG -CFL1030), using a sample from the $8^{\text {th }}$ leaf of the $2^{\text {nd }}$ branch from the apex of each plant.

Five plants from each treatment were selected for leaf, stem and root detachment and subsequent weighed to evaluate the fresh weight (Wf). The materials were dried in an oven at $60^{\circ} \mathrm{C}$ and weighed again to evaluate the dry weight (Wd).

\section{RESULTS AND DISCUSSION}

The tetrazolium test results showed that the lot 1 (one year of storage period) had $44 \%$ viable seeds, the lot 2 (two years of storage period) had $72 \%$ of viable seeds, and the lot 3 had unviable or dead seeds (Figure 1).

Regarding the lots 1 and 2, the differences in seed viability and vigor may be due to genetic variability between the progenitors, since these are from different environments and edaphoclimatic conditions, which allows a specific interaction between genotype and environment (SOUZA; KAGEYAMA; SEBBENN, 2004). Goes et al. (2014) found high genetic variability between natural populations of juazeiro in the Lower São Francisco region, which was directly related to the greater distance between these populations.

Regarding the seeds of lots 2 and 3, which were sampled from the same progenitors, the loss of germination capacity loss observed with three years of storage suggest the period in which there is a complete deterioration of juazeiro seeds. 


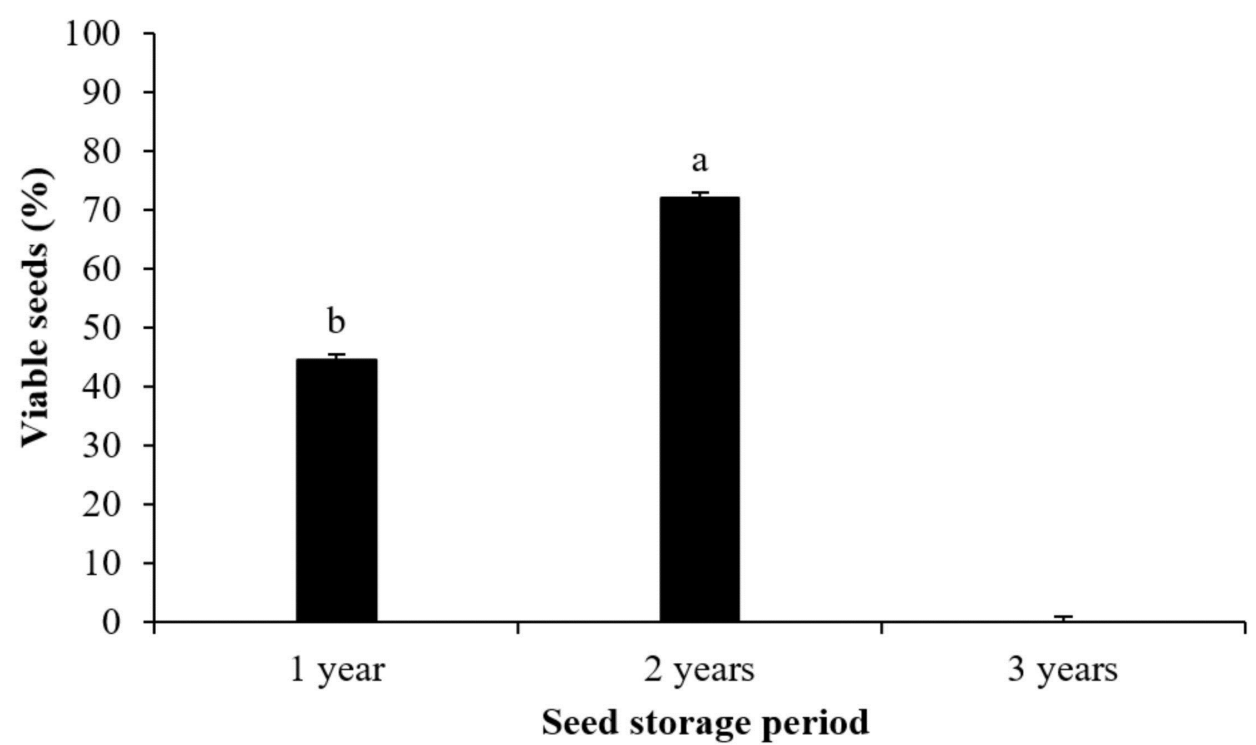

Figure 1. Percentages of viable juazeiro seeds from lots 1 (stored for one year), 2 (stored for two years) and 3 (stored for three years). Column with different letters differ by Tukey test at $5 \%$ probability.

The seed deterioration rate is directly dependent on the temperature and humidity of the environment in which they are stored, which is related to the acceleration of the metabolism and consequently consumption of seed reserves (MARCOS-FILHO, 2005; BARBEDO; CENTENO; FIGUEIREDO-RIBEIRO, 2013).

Mello et al. (2013) observed that Brazilwood (Caesalpinia echinata) seeds maintained a significant percentage of germination after five years of storage at $-8^{\circ} \mathrm{C}$, while those stored at $2^{\circ} \mathrm{C}$, deteriorated after three years. Guedes et al, 2012 also found that low temperatures promote longevity of aroeira (Myracrodruon urundeuva) seeds, with reductions of $87 \%\left(6^{\circ} \mathrm{C}\right)$ and $70 \%\left(-20^{\circ} \mathrm{C}\right)$ in germination after 240 days of storage, while seeds stored at $25^{\circ} \mathrm{C}$ were deteriorated after 150 days. Therefore, the storage conditions were, probably, not adequate to ensure longevity of the juazeiro seeds.

The application of pre-emergence treatment (Table 2), performed with seeds of lot 2, presented a high percentage of seedlings from untreated seeds $(93 \%)$, with no increase using scarification with sandpaper (T2). The scarification with hammer (T3) may have caused damage to the seed, presenting lower seedling emergence $(77 \%)$.

Table 2. Percentages of emergence and emergence speed index (ESI) of juazeiro seedlings from seeds subjected to pregermination treatments: control (T1), scarification with sandpaper (T2) and scarification with hammer (T3).

\begin{tabular}{ccc}
\hline Treatments & Emergence (\%) & ESI \\
\hline T1 (control) & 93 & 0,62 \\
$\mathrm{~T} 2$ & 93 & 0,59 \\
$\mathrm{~T} 3$ & $77^{*}$ & $0,46^{*}$ \\
\hline
\end{tabular}

\footnotetext{
*Significant at $5 \%$ average probability by the Dunnett test compared to the control.
}

The high percentage of seed emergence of the control suggests that the use of pre-germination treatment can be dispensed when the objective is to obtain high production of seedlings regardless the time required for germination.

However, the delay in germination of juazeiro seeds may be an indicative of dormancy. According to Mark-Son (2005), dormancy is an adaptive mechanism of many species for germination occurs in most appropriate period for growth of plants.
Regarding the emergence speed index (ESI), the physical methods were not effective in accelerate and uniform seedling emergence (Table 1), differing from the results found by Alves et al. (2008), who found ESI $168 \%$ higher than the control, with juazeiro seeds submitted to scarification with sandpaper. The difference in these results indicates the need for a more detailed study regarding the application of this method. Medeiros Filho et al. (2002) reported that the use of abrasive material 
requires great care in intensity and application form to not compromise the seed quality.

Regarding the relative frequency (Fr) (Figure $2)$, the emergence peak occurred 22 days after sowing (DAS) for all methods used, however, the control seedling emergence concentrated from 18 to 25 DAS, while the treatments with scarification had emergence with greater interval. The seeds submitted to scarification treatment with sandpaper (T2) had $13 \%$ of emergence after 30 DAS, while the and hammer treatment (T3) had 33\% of emergence after
30 DAS, extending up to the $66^{\text {th }}$ DAS. Brito and Osuna (2008) also found juazeiro seeds with long time for seedling emergence, in a slow and uneven process with percentage of $81 \%$ achieved at the $88^{\text {th }}$ DAS.

An increase in average emergence time (Tm) was observed in the seeds subjected to the scarification treatment. The scarification treatments with sandpaper (T2) and hammer (T3) had Tm of 24.8 and 27.4 days, respectively, while in the control treatment had Tm of 22.9 days.
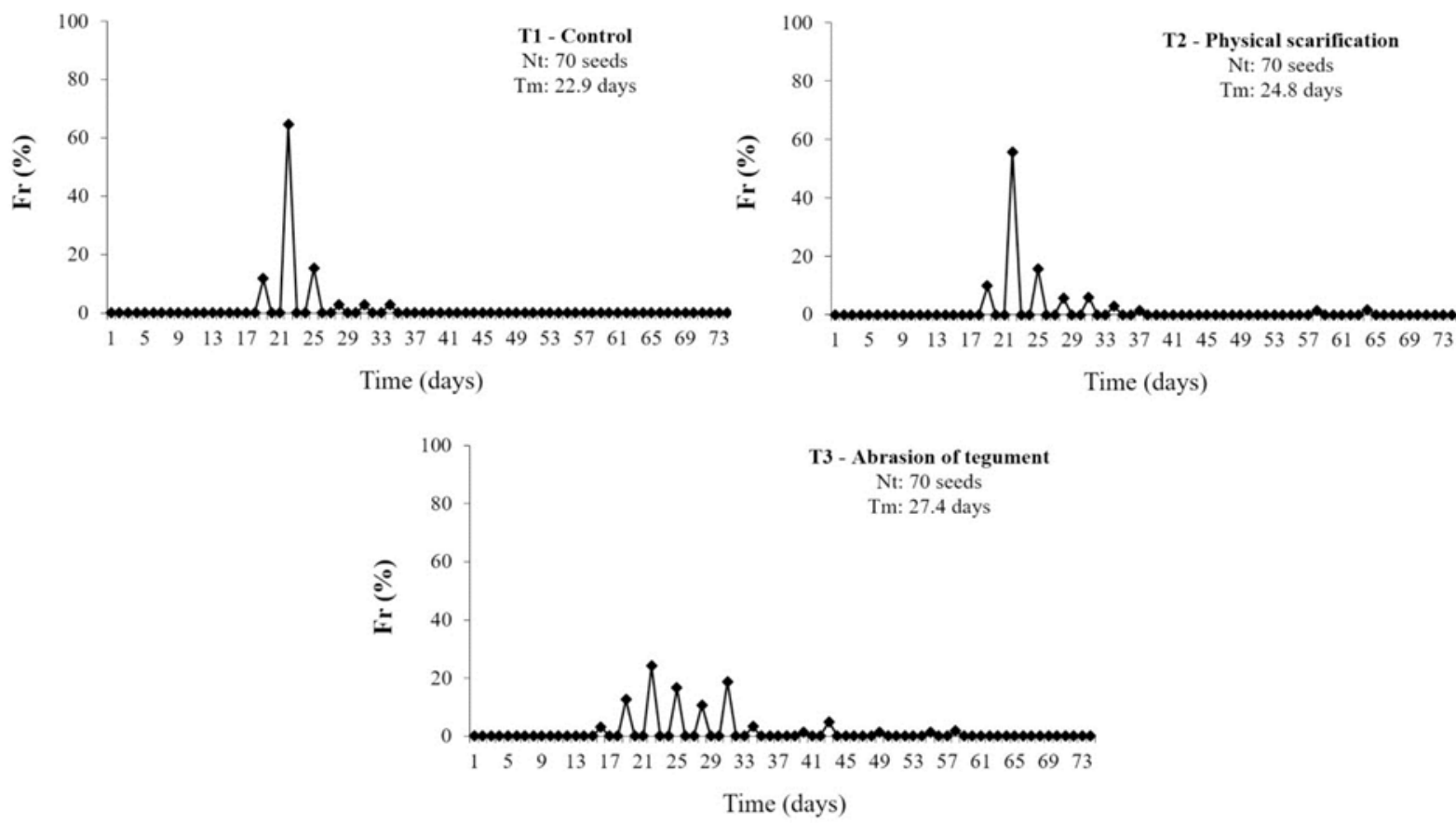

Figure 2. Emergence relative frequency $(\mathrm{Fr})$, total emergence $(\mathrm{Nt})$ and average emergence time $(\mathrm{Tm})$ of juazeiro seedlings from seeds subjected to pre-germination treatments: control (T1), scarification with sandpaper (T2) and scarification with hammer (T3).

Regarding the gas exchange, there were differences in the $\mathrm{CO}_{2}$ assimilation between the juazeiro plants grown in different soils only at the $09 \mathrm{~h} 00$ and $11 \mathrm{~h} 00$ readings (Figure 3A).

The gas exchange measures started immediately after irrigation. The plants grown on Vertisol presented lower photosynthetic rates at $09 \mathrm{~h} 00$, probably due to its low drainage associated with the type of clay, smectite, which is prevailing in this soil class, and can cause temporary flooding after irrigation and hence limiting the root respiration. Therefore, the moisture distribution occurs slowly until adequate aeration conditions are restored for the root system, which may have occurred by $11 \mathrm{~h} 00$, when the photosynthetic rate of plants was practically equal to the rates of the plants grown in Oxisol and Entisol.

On the other hand, the Oxisol and Entisol, typically well drained soils, enable a rapid distribution of water after irrigation, with adequate aeration for the roots, which may have caused higher photosynthetic rates at $09 \mathrm{~h} 00$.
Regarding the transpiration rates, no significant differences were found between the plants grown on different soils, as well as throughout the day for the same soil type (Figure 3E). This fact is probably related to the lack of water stress in the soil during the evaluation period. Silva et al. (2004) found higher transpiration rates of juazeiro occurring at $10 \mathrm{~h} 00$ for non-irrigated conditions, decreasing considerably during the afternoon.

There was a gradual decrease in photosynthetic activity of juazeiro plants after $13 \mathrm{~h} 00$, regardless of the type of soil, possibly related to the partial closing of the stomata, since there was a reduction in stomatal conductance (Figure 3B), and to the increase in leaf temperature (Figure 3C) around this period. Santos, Silva and Silva Junior (2014) also found carbon assimilation gradually reducing throughout the day in juazeiro, but with lower rates, ranging from de $4 \mu \mathrm{mol} . \mathrm{m}^{-2} \mathrm{~s}^{-1}$ at $08 \mathrm{~h} 00$ to $1 \mu \mathrm{mol} . \mathrm{m}^{-2} \mathrm{~s}^{-1}$ at $16 \mathrm{~h} 00$. 

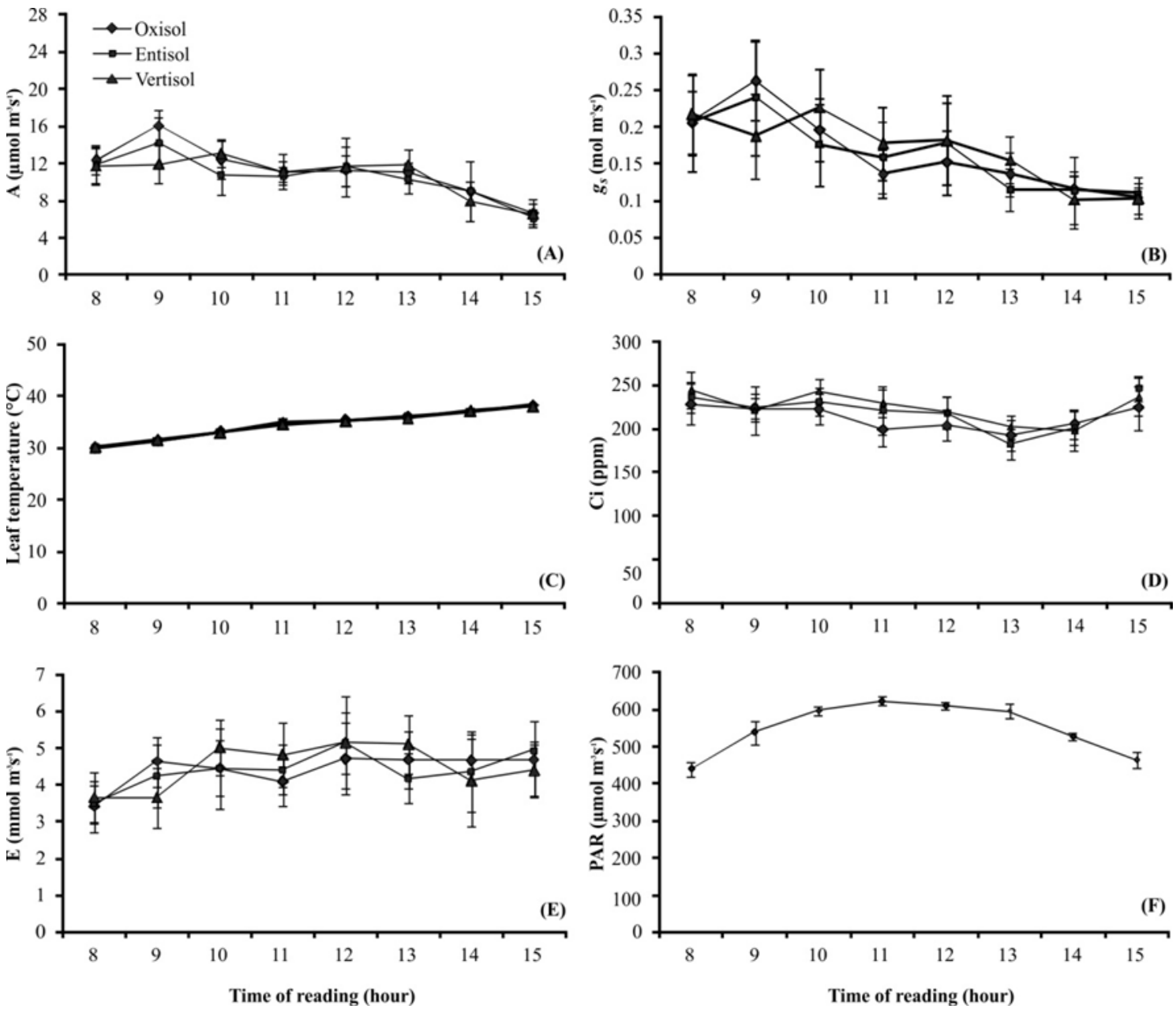

Figure 3. Photosynthetic activity (A), stomatal conductance (B), leaf temperature (C), internal $\mathrm{CO}_{2}$ concentration (D), transpiration (E) and photosynthetically active radiation (F) in juazeiro plants grown in three types of soil (Entisol, Oxisol and Vertisol).

The internal $\mathrm{CO}_{2}$ concentration also increased after the time $13 \mathrm{~h} 00$ (Figure 3D), due to the accumulation of the $\mathrm{CO}_{2}$ that was not used by plants because the reduction in photosynthetic rate, which may be related to the decrease in light availability during this period (SANTRUCEK et al., 2014). Moreover, there is the contribution of the higher stomatal closure after that time, which resulted in accumulation of $\mathrm{CO}_{2}$ from the cellular respiration and photorespiration activity in the mesophyll cells (ROUSSEL; IVLEV; IGAMBERDIEV, 2007).

The maximum photosynthetic efficiency can be achieved with light incidence from $500 \mu \mathrm{mol} \mathrm{m}$ $\mathrm{s}^{-1}$ (TAIZ; ZEIGER, 2013), thus, the availability of up to $600 \mu \mathrm{mol} \mathrm{m} \mathrm{m}^{-2} \mathrm{~s}^{-1}$ photons to the juazeiro plants (Figure $3 \mathrm{~F}$ ) could avoid effects of photo-inhibition, due to excessive radiation levels in the region, reaching values above $2,000 \mu \mathrm{mol} \mathrm{m}^{-2} \mathrm{~s}^{-1}$.

No differences in leaf chlorophyll index were found between juazeiro plants in the different soils, the radiation influenced the chlorophyll $a$ and $b$ rates, reaching values of 39 and 14 ICF (Chlorophyll Index Falker). The chlorophyll $a /$ chlorophyll $b$ ratio was 2.79. Yamazaki (2010) found ratio of chlorophyll $a$ / chlorophyll $b$ ranging from 1.7 in rice plants placed in the dark to 3.7 to plants exposed to natural light, which confirms that the production of chlorophyll $a$ exceeds the chlorophyll $b$ with less exposure to the sun.

Regarding the initial growth of juazeiro plants in the different types of soil, the evaluation of the variables main branch length and stem diameter the plant showed slow growth, regardless of the type of soil used, with an average increase of only $50 \mathrm{~cm}$ in five months (Figure 4). The fresh and dry matter of the leaves, stems and roots, also showed no significant differences between the plants grown in different soils (Figure 5). 

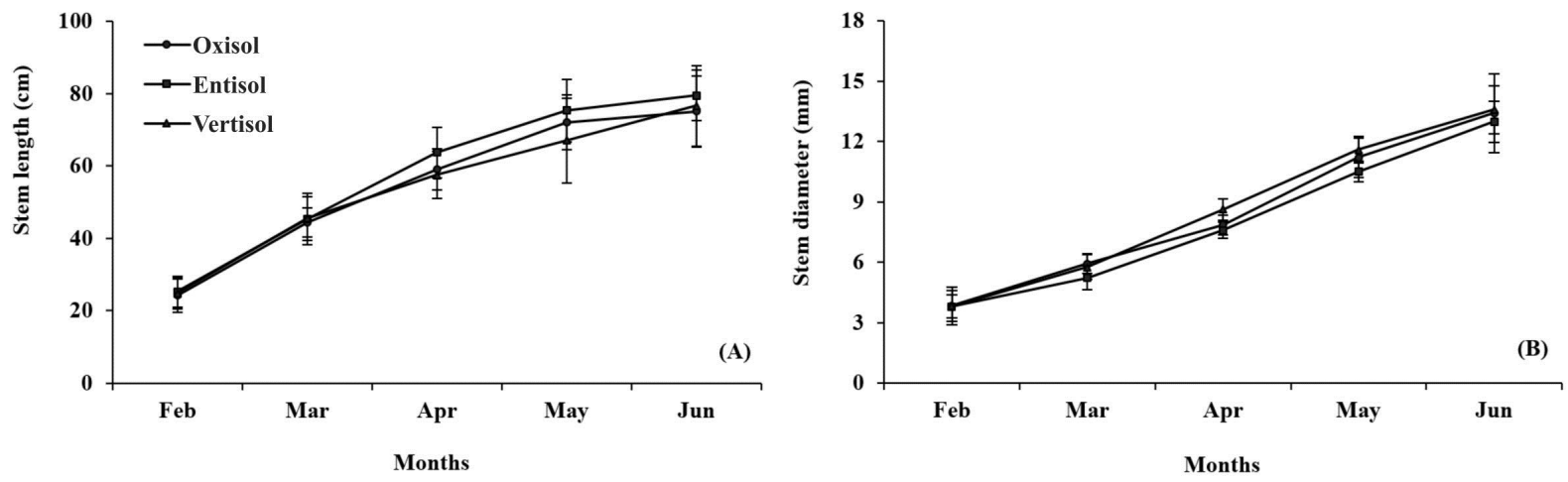

Figure 4. Monthly measurements of the main branch length (A) and stem diameter (B) of juazeiro plants grown in three soil types (Entisol, Oxisol and Vertisol).
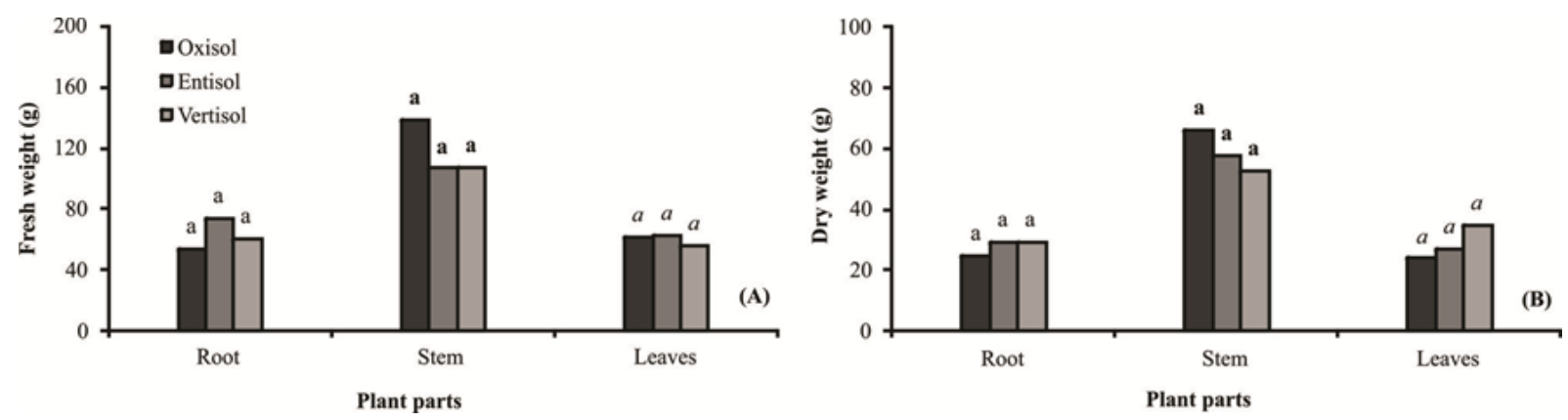

Figure 5. Fresh (A) and dry (B) weight of the root, stem and leaves of juazeiro plants grown in three soil types (Oxisol, Entisol and Vertisol). Columns with the same letter in the soil classes do not differ by Tukey test at $5 \%$ probability.

These results denote the photosynthetic similarity of the plants under three types of soil, showing that the chemical and physical properties specific to each soil such as texture, structure, porosity, $\mathrm{pH}$ and nutrient availability, were not sufficient to interfere with the assimilate production and, consequently, alter plant growth. The total amount of the plant dry matter accumulation is direct reflection of the net photosynthetic production, plus the amount of absorbed mineral nutrients (REGO; POSSAMAI, 2006).

Thus, the juazeiro plants have high growth potential in different edaphic environments, which indicate a long adaptation process of this species to the limitations inherent in their natural habitat.

\section{CONCLUSIONS}

The viability of juazeiro seeds is greatly influenced by differences between the progenitor plants and by storage conditions, which enable a longevity of two years when stored at $22^{\circ} \mathrm{C}$ and $16 \%$ of relative humidity.

The scarification methods with sandpaper and hammer are not recommended to reduce the time and uniform the germination of juazeiro seeds.

The juazeiro plants have high growth potential in different edaphic environments, adapting well to soils of different textures and chemical compositions.

\section{ACKNOWLEDGEMENTS}

The authors thank the National Counsel of Technological and Scientific Development (CNPq) by granting Scientific Initiation scholarships.

\section{REFERENCES}

ABBADE, L.C.; TAKAKI, M. Teste de tetrazólio para avaliação da qualidade de sementes de Tabebuia roseoalba (Ridl.). Sandwith Bignoniaceae, submetidas ao armazenamento. Revista Árvore, Viçosa, v. 38, n. 2, p. 233-240, 2014.

ALVES, A, R. et al. Análise da estrutura vegetacional em uma área de caatinga no município de Bom Jesus, Piauí. Revista Caatinga, Mossoró, v. 26, n. 4, p. 99-106, 2013.

ALVES E. U. et al. Métodos para quebra de dormência de unidades de dispersão de Zizyphus joazeiro Mart.(RHAMNACEAE). Revista Árvore, Viçosa, v. 32, n. 3, p. 407-415, 2008.

ALVES, E. U. et al. Ácido sulfúrico na superação da dormência de unidades de dispersão de juazeiro (Zizyphus joazeiro Mart.). Revista Árvore, Viçosa, v. 30, n. 2, p. 187-195, 2006. 
ARAÚJO-NETO, J. C. et al. Caracterização morfológica de frutos e sementes e desenvolvimento pós-seminal de monjoleiro (Acacia polyphylla DC.). Revista Brasileira de Sementes, Londrina, v. 24, n. 1, p. 203-211, 2002.

ARCOVERDE, S. N. S. et al. Qualidade física de solos em uso agrícola na região semiárida do Estado da Bahia. Revista Brasileira de Ciência do Solo, Viçosa, v. 39, n. 5, p. 1473-1482, 2015

AZEREDO, G. A. et al. Superação de dormência de sementes de Piptadenia moniliformis Benth. Revista Brasileira de Sementes, Londrina, v. 32, n. 2, p. 49$58,2010$.

BARBEDO, C. J.; CENTENO, D. C.; FIGUEIREDO-RIBEIRO, R. C. L. Do recalcitrant seeds really exist?. Hoehnea, São Paulo, v. 40, n. 4, p. 583-593, 2013.

BENTO, S. R. S. O. et al. Eficiência dos testes de vigor na avaliação da qualidade fisiológica de sementes de mulungu (Erythrina velutina WILLD.). Revista Brasileira de Sementes, Londrina, v. 32, n. 4, p. 111-117, 2010.

BRASIL. Ministério do Meio Ambiente. Síntese das discussões e recomendações do componente biodiversidade da Caatinga. Disponível em: $<$ http:// www.mma.gov.br/estruturas/203/_arquivos/ produto_icid_analuce_203.pdf $\geq$. Acesso em: $18 \mathrm{fev}$. 2015.

BRITO, K. L. M.; OSUNA, J. T. A. Influência dos tratamentos físicos e químicos na germinação de Ziziphus joazeiro Mart. (RHAMNACEAE). Magistra, Cruz das Almas, v. 20, n. 1, p. 16-21, 2008 .

CPRM. Projeto Cadastro de Fontes de Abastecimento por Água Subterrânea: Diagnóstico do município de Juazeiro - Bahia. Salvador, 2005. 33 p.

DANTAS, B. F.; MATIAS, J. R.; RIBEIRO, R. C. Teste de tetrazólio para avaliar viabilidade e vigor de sementes de espécies florestais da Caatinga. Informativo Abrates, Londrina, v. 25, n. 1, p. 6064, 2015

DE-POLLI, H.; GUERRA, J. G. M. C, $\mathrm{N}$ e $\mathrm{P}$ na biomassa microbiana do solo. In: SANTOS, G. A., CAMARGO, F. A. O. (Eds.) Fundamentos da matéria orgânica do solo: ecossistemas tropicais e subtropicais. Porto Alegre: Gênesis, 1999. V. único, cap. 17, p. $389-412$.

FRANÇA-NETO, J. D. O teste de tetrazólio em sementes de soja. Jaboticabal, SP: Funep, 1994. p.
$87-102$.

GOIS, I. B. et al. Variabilidade genética em populações naturais de Ziziphus joazeiro Mart., por meio de marcadores moleculares RAPD. Revista Árvore, Viçosa, v. 38, n. 4, p. 621-630, 2014.

GUEDES, R. S. et al. Armazenamento de sementes de Myracrodruon urundeuva Fr. All. em diferentes embalagens e ambientes. Revista Brasileira de Plantas Medicinais, Campinas, v. 14, n. 1, p. 68-75, 2012.

GUEDES, R. S. et al. Metodologia para teste de tetrazólio em sementes de Amburana cearensis (Allemão) A.C. Smith. Revista Brasileira de Plantas Medicinais, Botucatu, v. 12, n. 1, p. 120126,2010

LABOURIAU, L. G.; VALADARES, M. E. B. On the germination of seeds Calotropis procera (Ait.) Ait.f. Anais da Academia Brasileira de Ciências, Rio de Janeiro. v. 48, n. 2, p. 263-284, 1976

LACERDA, R. M. A; LIRA-FILHO, J. A.; SANTOS, R. V. Indicação de espécies de porte arbóreo para a arborização urbana no semi-árido paraibano. Revista da Sociedade Brasileira de Arborização Urbana, Piracicaba, v. 6, n. 1, p. 5168, 2011.

MAGUIRE, J. D. Speed of germination-aid in selection and evaluation for seedling emergence and vigor. Crop Science, Madison, v. 2, n. 2, p. 176-177, 1962.

MARCOS-FILHO, J. Fisiologia de sementes de plantas cultivadas. 1 . ed. Piracicaba, SP: FEALQ, 2005. $495 \mathrm{p}$

MEDEIROS FILHO, S.; FRANÇA, E. A.; INNECCO, R. Germinação de sementes de Operculina macrocarpa (L.) Farwel e Operculina alata (Ham.) Urban. Revista Brasileira de Sementes, Londrina, v. 24, n. 2, p. 102-107, 2002.

MELLO, J. I. O.; FIGUEIREDO-RIBEIRO, R. C. L.; BARBEDO, C. J. Sub-zero temperature enables storage of seeds of Caesalpinia echinata Lam. Journal of Seed Science, Londrina, v. 35, n. 4, p. 519-523, 2013.

MEURER, E. J. Fatores que influenciam o crescimento e desenvolvimento das plantas. In: NOVAIS, R. F. et al. (Eds.). Fertilidade do solo. Viçosa: Sociedade Brasileira de Ciência do Solo, 2007. vol. único, cap. 2, p. 65-90.

MOTTA, A. C. V. et al. Distribuição horizontal e vertical da fertilidade d Distribuição horizontal e 
vertical da fertilidade do solo e das o solo e das raízes de cafeeiro (Coffea arabica L.) cultivar Catuaí. Acta Scientiarum. Agronomy, Maringá, v. 28, n. 4, p. 455-463, 2006.

NADIA, T. L; MACHADO, I. C.; LOPES, A. V. Fenologia reprodutiva e sistema de polinização de Ziziphus joazeiro Mart. (Rhamnaceae): atuação de Apis mellifera e de visitantes florais autóctones como polinizadores. Acta Botanica Brasilica, São Paulo, v. 21, n. 4, p. 835-845, 2007.

OLIVEIRA, A. K. et al. Atividade alelopática de extratos de diferentes partes de juazeiro (Ziziphus joazeiro Mart. - Rhamnaceae). Acta Botanica Brasilica, Feira de Santana, v. 26, n. 3, p. 685-690, 2012.

OLIVEIRA, L. B. et al. Morfologia e classificação de Luvissolos e Planossolos desenvolvidos de rochas metamórficas no Semiárido do Nordeste Brasileiro. Revista Brasileira de Ciência do Solo, Viçosa, v. 33, p. 1333-1345, 2009.

REGO, G. M.; POSSAMAI, E. Efeito do Sombreamento sobre o Teor de Clorofila e Crescimento Inicial do Jequitibá-rosa. Boletim de Pesquisa Florestal, Colombo, v. 26, n. 53, p. 179194, 2006.

ROUSSEL, M. R.; IVLEV, A. A.; IGAMBERDIEV, A. U. Oscillations of the internal $\mathrm{CO}_{2}$ concentration in tobacco leaves transferred to low $\mathrm{CO}_{2}$. Journal of Plant Physiology, Stuttgart, v. 164, n. 9, p. 11881196, 2007.

SANTANA, J. A. S. et al. Levantamento florístico e associação de espécies na caatinga da Estação Ecológica do Seridó, Serra Negra do Norte - RN. Revista Verde de Agroecologia e Desenvolvimento Sustentável, Mossoró, v. 4, n. 4, p. 83-89, 2009.

SANTOS, L. M. J.; SILVA, E. C.; SILVA JUNIOR, C. D. Análise preliminar das trocas gasosas, fluorescência da clorofila e potencial hídrico de plantas de juazeiro em uma região semi-árida de Sergipe, Brasil. Scientia Plena, Aracaju, v. 10, n. 2, p. 1-10, 2014.

SANTRUCEK, J. et al. Stomatal and pavement cell density linked to leaf internal $\mathrm{CO}_{2}$ concentration. Annals of Botany, Oxford, v. 114, n. 1, p. 191-202, 2014.

SILVA, E. C. et al. Aspectos ecofisiológicos de dez espécies em uma área de caatinga no município de Cabaceiras, Paraíba, Brasil. Iheringia Série Botânica, Porto Alegre, v. 59, n. 2, p. 201-205, 2004.
SOUZA, L. M. F. I.; KAGEYAMA, P. Y.; SEBBENN, A. M. Estrutura genética em populações fragmentadas de Chorisia speciosa St. Hil (Bombacaceae). Scientia Forestalis, Piracicaba, v. 32 , n. 65 , p. 70-79, 2004.

TAIZ, L; ZEIGER, E. Fisiologia Vegetal. 5. ed. Porto Alegre, RS: ARTMED, 2013. 954 p.

YAMAZAKI , J. Is light quality involved in the regulation of the photosynthetic apparatus in attached rice leaves?. Photosynthesis Research, Dordrecht, v. 105, n. 1, p. 63-71, 2010. 